\title{
Mating and sperm transfer in Apis florea
}

\author{
N. Koeniger, G. Koeniger and S. Wongsiri
}

Chulalongkorn University, Faculty of Science, Department of Biology, Bee Biology Research Unit, Bangkok 10500, Thailand

(received 5 July 1989, accepted 20 August 1989)

\begin{abstract}
Summary - The mating flights of 3 virgin queens of Apis florea have been observed. The queens carried no mating sign when they returned to their colonies. In 2 of the queens, dissected several minutes following their return, spermatozoa were found in the spermatheca. The filling of the spermatheca during mating and the anatomical structure of the Apis florea drone's endophallus suggested direct sperm transfer into the spermatheca. The 3rd queen was dissected $16 \mathrm{~h}$ after mating. At that time, more than 200 eggs were present in the previously emply comb. The queens had 0.48 , 0.72 and 1.35 million spermatozoa in the spermatheca. On average, drones of $A$. florea were found to produce about 0.44 million spermatozoa. So, the queens were presumely mated by 1,2 and 3 drones, respectively.
\end{abstract}

Apis florea - mating - sperm transfer

\section{INTRODUCTION}

The mating behaviour and sperm transfer of the Western honeybee Apis mellifera and the Eastern hive bee $A$. cerana seem to follow a similar pattern. For mating, the young virgin queen leaves the hive and flies to a drone congregation area. There the queen mates high in the air with, on average, 6 to 12 drones. In $A$. cerana, polyandry seems to occur to a similar extent. Woyke (1975) calculated that $A$. cerana queens are mated by an average of 10 drones.

During mating, the first drone inserts his endophallus into the bursa copulatrix of the queen and ejaculates his spermatozoa into the oviducts of the queen. Then the queen separates from the drone, which falls paralyzed to the ground. The drone's mating sign (mucus plus some orange pigment) remains in the queen's sting chamber. Each consecutive drone inserts his endophallus beneath the mating sign of his predecessor and removes it by a special organ on the endophallus (Koeniger, 1986). In the course of copulation, each drone deposits his spermatozoa into the oviducts and leaves the mating sign in the queen. After the last mating, the queen returns to the hive carrying the mating sign of the last drone in her sting chamber. The mating sign is clearly visible to the naked eye. 
After mating, the spermatozoa are transferred from the oviduct into the spermatheca. More than $90 \%$ of the spermatozoa are lost during this transportation process. In $A$. mellifera about 6-8 million spermatozoa are found in a fully mated young queen, while the $A$. cerana queen has only 1.3-3.5 million spermatozoa in the spermatheca (Ruttner et al., 1973).

The number of spermatozoa of drones differ between both species. A. mellifera drones have $10-11$ million spermatozoa (A. mellifera carnica) in their seminal vesicles, while $A$. cerana drones contain only 1 million spermatozoa (Woyke, 1975)

In $A$. florea, the only previously reported details are spermatozoa counts from the spermathecae of 2 laying queens, where 0.38 and 0.922 million spermatozoa were found (Ruttner, 1988).

\section{MATERIAL AND METHODS}

\section{Colony management and queen pro- duction}

Colonies of $A$. florea were collected from the campus of Chulalongkorn University in Bangkok and from Mae Klong village $(70 \mathrm{~km}$ south east of Bangkok). The colonies were installed at 2 balconies in the first story of the biology building. After an initial orientation period of 2 days, the queens were removed from the colonies and dissected. Ten days after removal of the queens, the colonies were inspected and all sealed queen cells were cut out from the comb together with some surrounding comb cells. Each queen cell was kept in its natural orientation in a small plastic cage and placed into an incubator at $34.5^{\circ} \mathrm{C}$ and $60 \%$ relative humidity. Sixteen days after the removal of the queen, the first queen cells hatched. Each young queen was marked by a numbered plastic tag on the thorax and introduced into a queenless colony, where the young queen was observed daily from 12.00 to 16.00 (local time). Our previous observations showed that drone flights of $A$. flor$e a$ in Bangkok occurred between 13.45 and 15.30. Surplus queens were kept in small cages with an escort of 20 workers and fed with candy for several days. The workers were changed after 3 days.

\section{Dissection and counting of spermato- zoa}

Drones were caught at the colony when they returned from their mating flights. They were kept in a cage (without workers) for about 12 to $16 \mathrm{~h}$ until their movements were slow. This treatment prevented the drones from emptying the vesicles when being killed. Then the vesiculae seminales were carefully isolated and transferred into $1 \mathrm{ml}$ of $0.9 \mathrm{NaCl}$ solution. The vesicles were opened and the sperm evenly dispersed. For counting, a Fuchs-Rosenthal counting chamber (haemocytometer) was used.

The original queens were dissected immediately after removal from the colony. Each spermatheca was isolated and its tracheal net removed. Then the intact spermatheca was transferred into $1 \mathrm{ml}$ of $0.9 \% \mathrm{NaCl}$ solution, where the spermatozoa were evenly distributed. Again, a Fuchs-Rosenthal chamber was used for counting. In the freshly mated queens the oviducts were examined for spermatozoa under a microscope.

\section{RESULTS}

\section{Number of spermatozoa in drones and queens}

We counted the vesiculae seminales of 8 drones (Table 1). The average number of spermatozoa was 0.44 million per $A$. florea 
Table I. Number of spermatozoa (in millions) and body mass of drones.

\begin{tabular}{lcl}
\hline $\begin{array}{c}\text { Drone } \\
\text { No. }\end{array}$ & $\begin{array}{c}\text { Weight } \\
(\mathrm{mg})\end{array}$ & $\begin{array}{c}\text { Spermatozoa } \\
\text { (millions) }\end{array}$ \\
\hline & 90.7 & 0.45 \\
1 & 82.7 & 0.46 \\
2 & 86.9 & 0.4 \\
3 & 80.9 & 0.39 \\
4 & 87.9 & 0.49 \\
5 & - & 0.48 \\
6 & - & 0.45 \\
7 & - & 0.41 \\
8 & 85.8 & $0.44 \pm 0.037$ \\
Average & &
\end{tabular}

drone. The results of sperm counting in laying queens of unknown age are shown in Table II. The maximum number found was 1.35 million.

\section{Premating behaviour}

The first queen emerged on Feb. 5th and was labelled and introduced into a queenless colony that day. During the first days the queen patrolled (Lindauer, 1952) main- ly on the comb beneath the curtain of bees which covered the colony. On days 3 and 4 , the queen crossed the platform (upper portion of the comb) several times. The movements of the queen by this time were much faster and the workers which came into contact with the queen on the platform reacted with dorso-ventral vibrations, as described for $A$. mellifera scutellata (Fletcher, 1977). On the 6th day the queen entered the platform. She ran fast with several sudden breaks during which she displayed intensive cleaning behaviour. At the

Table II. Number of spermatozoa (in millions) found in the spermatheca of laying queens collected in Thailand.

\begin{tabular}{lll}
\hline $\begin{array}{c}\text { Queen } \\
\text { no. }\end{array}$ & $\begin{array}{c}\text { Spermatheca } \\
\text { (without tracheas) } \\
\text { diameter }(\mathrm{mm})\end{array}$ & $\begin{array}{c}\text { Spermatozoa } \\
\text { (million) }\end{array}$ \\
\hline 1 & 0.825 & 0.85 \\
2 & 0.75 & 0.25 \\
3 & 0.81 & 1.2 \\
4 & 0.8 & 1.2 \\
5 & 0.75 & 0.62 \\
6 & 0.7 & 1.35 \\
7 & 0.8 & 0.8 \\
\hline
\end{tabular}


same moment, cleansing and orientation flights of the workers took place. The queen started flying at 13.44 and returned, after some circling around, to the colony at 13.46.

On the 7 th day, the queen frequently crossed the platform and the dorso-ventral movements of the workers near her became intensive. No drone flight occurred during this day.

\section{Mating flight and sperm transfer}

On the 8th day, the queen started flying at 14.16 and flew away in a straight line high up in the sky. She returned at 14.34 and was caught at once. No mating sign was found but nevertheless, we dissected her without delay. Her spermatheca was examined 10 min after her return; it was filled with fast moving spermatozoa. We counted 0.48 million spermatozoa from the spermatheca. The oviduct was rinsed in $\mathrm{NaCl}$ solution and the fluid was carefully inspected under a microscope. We detected 15 moving spermatozoa.

The second queen had a short flight (2 min) on her 5th day. On the 6th day she started flying at 14.04 and returned at 14.25. Again, no mating sign was observed and the examination of the queen's spermatheca only $5 \mathrm{~min}$ afterwards showed there to be 0.72 million spermatozoa in her spermatheca. No spermatozoa were detected in the oviducts.

\section{Start of oviposition}

The third queen flew on the 7th day of her life from 15.02 until 15.32 and returned without a mating sign. This queen was al- lowed to stay in the colony for $16 \mathrm{~h}$, after which we found 200 freshly laid eggs in the comb. The comb did not contain eggs 1 day before. The queen had 1.17 million spermatozoa in her spermatheca. None was found in the oviducts.

The fourth queen flew 8 days after emergence and left from 14.00 until 14.15. Her spermatheca and oviducts were empty.

\section{DISCUSSION}

These first observations of the mating flight of $A$. florea were carried out with a limited number of virgin queens and at one location. Nervertheless, data from the 3 queens allow some conclusions to be drawn on the mating of $A$. florea. Apparently, no mating sign is left in the queen's sting chamber after mating and the sperm is transferred directly into the spermatheca. Anatomical 'evidence' for a direct sperm transfer into the spermatheca can be concluded from the morphology of the genital organs. The $A$. florea drone has rudimentary mucus glands and no mucus for a mating sign is produced. In contrast to $A$. mellifera, where the drone is attached during the copulation to the queen by the endophallus filled with mucus (Koeniger, 1986), the A. florea drone has clasper organs at the basitarsus of its hind leg which are suitable and may function to hold the queen's leg (Ruttner, 1975). The endophallus of $\boldsymbol{A}$. florea is "an isolated, highly specialized type within the genus Apis " (Ruttner, 1988). The shape of this endophallus, especially the tip at the distal end, seems to fit the hypothesis of direct sperm transfer (Fig. 1). Anatomical studies of the queen's genitalia and the ductus spermaticus are in preparation. 

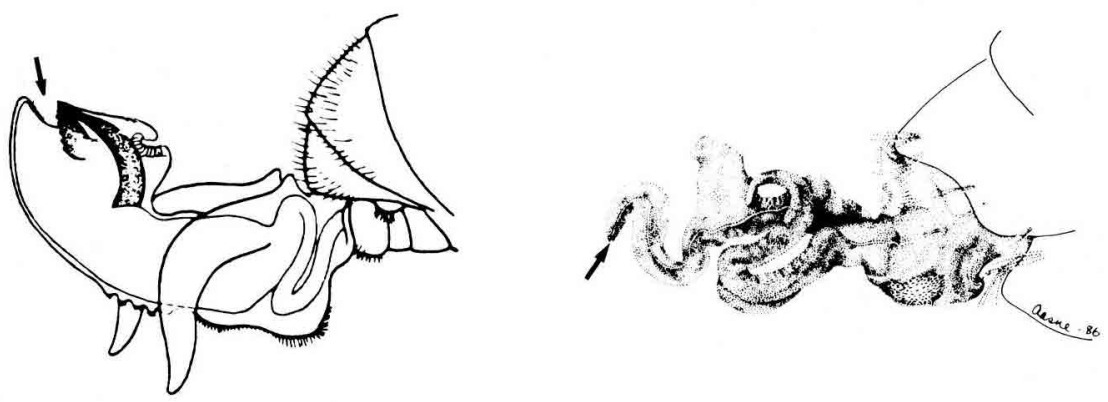

Fig. 1. Everted endophallus: a. Apis mellifera (stage of ejaculation); bulb short and broad; b. Apis florea; bulb elongated with thin tip (arrow = opening of ejaculatory duct).

Furthermore the number of spermatozoa found in the spermathecae of the freshly mated queens seems to be related to the number of matings. One $A$. florea drone has an average of 0.44 million spermatozoa (Table I). So we can assume that

i) the first queen ( $0.48 \mathrm{mio}$ ) was inseminated by 1 drone;

ii) the second queen ( 0.72 mio) was inseminated by 2 drones;

ii) the third queen (1.17 mio) was inseminated by 3 drones.

This idea again is based on direct sperm transfer into the spermatheca, which can function without major losses of spermatozoa. Under these assumptions, the number of spermatozoa found in laying $A$. florea queens (Table II) indicates that $A$. florea queens copulate with a maximum of 4 drones. The largest number found was 1.35 million. This could be the result of 3 to 4 matings. So, the degree of female polygamy in $A$. florea is much lower than in $A$. mellifera or A. cerana.

In $A$. mellifera and A. cerana about $90 \%$ of the spermatozoa deposited by the drones in the oviducts gets lost, with only $10 \%$ reaching the spermatheca. This transport of spermatozoa within the queen is in- efficient compared to the direct transfer of spermatozoa into the spermatheca during mating by drones of $A$. florea.

Résumé - Accouplement et transfert de sperme chez Apis florea. On a observé le vol nuptial de 3 reines vierges d'Apis florea. Elles ne portaient pas de signes d'accouplement lorsqu'elles sont rentrées à la ruche. Deux des reines, disséquées quelques minutes après leur retour, avaient leur spermathèque remplie de spermatozoïdes. On n'a relevé aucune quantité notable de sperme dans les oviductes. Cette observation, ainsi que la structure anatomique de l'endophallus du mâle, suggèrent le transfert direct du sperme dans la spermathèque lors de l'accouplement chez cette espèce. La troisième reine a été disséquée $16 \mathrm{~h}$ après l'accouplement. A ce moment là plus de 200 œufs étaient présents dans les cellules du rayon, vides à l'origine.

Les reines renfermaient dans leur spermathèque $0,48,0,72$ et 1,35 million de spermatozoïdes. L'examen des vésicules séminales des mâles a montré qu'elle contenaient environ 0,44 million de sper- 
matozoïdes. On peut donc penser que les reines se sont accouplées avec 1, 2 ou 3 mâles, respectivement.

Zusammenfassung - Paarungsverhalten und Spermatransfer bei der Zwerghonigbiene Apis florea. Der Hochzeitsflug von 3 jungfräulichen Königinnen wurde am Volk beobachtet. Die Königinnen kehrten vom Paarungsflug ohne Begattungszeichen zurück. Zwei Königinnen, die wenige Minuten nach ihrer Rückkehr präpariert wurden, hatten bereits eine mit Spermien gefüllte Spermatheka. In den Ovidukten waren keine nennenswerten Spermamengen vorhanden. Diese Beobachtung sowie der anatomische Bau des Endophallus des Drohns sprechen für eine direkte Spermaübertragung in die Spermatheka bei der Paarung von Apis florea. Die dritte Königin wurde 16 Stunden nach Rückkehr vom Paarungsflug präpariert. Zu diesem Zeitpunkt wurden bereits mehr als 200 Eier in den vorher leeren Wabenzellen gefunden.

Die Königinnen hatten 0,48 Millionen, 0,72 Millionen und 1,35 Millionen Spermien in den Spermatheken. Eine Überprüfung der Vesiculae seminales der
Drohnen ergab eine durchschnittliche Spermazahl von 0,44 Milionen. So kann vermutet werden, daß die Königinnen von jeweils 1, 2 und 3 Drohnen begattet worden waren.

\section{REFERENCES}

Fletcher D.J.C. (1978) The influence of vibratory dances by worker honey bees on the activity of virgin queens. J. Apic. Res. 17, 3-13

Koeniger G. (1986) Mating sign and multiple mating. Bee World 67, 141-150

Lindauer M. (1952) Ein Beitrag zur Frage der Arbeitsteilung im Bienenstaat. Z. Vergl. Physiol. 34, 299-345

Ruttner F. (1975) Ein metatarsaler Haftapparat bei den Drohnen der Gattung Apis (Hymenoptera, Apidae). Entomol. German. 2, 22-29

Ruttner F. (1988) Biogeography and Taxonomy of Honey bees. Springer Verlag, Berlin/ Heidelberg/ New York, 284 pp.

Ruttner F., Woyke J. \& Koeniger N. (1973) Reproduction in Apis cerana. 2. Reproductive organs and natural insemination. J. Apic. Res. 12, 21-34

Woyke J. (1975) Natural and instrumental insemination of Apis cerana indica in India. $J$. Apic. Res. 14, 153-159 